\title{
GEREJA MENGUMAT DI MASA PANDEMI COVID-19 BAGI KEHIDUPAN BERIMAN MAHASISWA RANTAU DI MALANG (DALAM TERANG LUMEN GENTIUN ART. 13)
}

\author{
Tomy Taroreh, Antonius Denny Firmanto ${ }^{* 1}$, Nanik Wijiyati Aluwesia ${ }^{* 2}$ \\ SekolahTinggi Filsafat Teologi Widya Sasana Malang \\ tomytaroreh@gmail.com \\ *)1 penulis korespondensi,rm_deni@yahoo.com \\ ${ }^{* 22}$ penulis korespondensi, naniwa9@gmail.com
}

\begin{abstract}
The church is called catholic because it is open and intended for anyone. The presence of the Church during the Covid-19 Pandemic should really be felt in the life of faith, especially for Catholic students who have migrated to Malang. The church must not shut down and avoid the needs of God's people, despite the compelling circumstances of the era. The church must be committed to God's mission in a creative way, which is to spread the gospel throughout the world. In research on the presence of the church in the pandemic time Covid-19 for belief life, overseas catholic students in Malang will use the questionnaire method to obtain data. The questionnaire is for Catholic students who have migrated to Malang. The results of the study showed that most of the Catholic students understand about the Corona Virus Pandemic and most of them live in rented houses. The church still feels that it continues to try to greet them even though the situation is not supportive, even for students who migrate to Malang. Students actually feel a sense of abandonment because of a pandemic that never ends and which causes church life to not return to normal soon.
\end{abstract}

Keywords: Church Mission, Youth, Corona Virus, God's People, Catholic

\section{PENDAHULUAN}

Dunia semakin berkembang dan semakin maju, zaman menjadi semakin berubah bahkan hingga kini dunia mengalami pandemi Covid-19. Ya, itulah realita yang harus dihadapi oleh manusia dewasa ini. Berbagai perkembangan dan persoalan selalu menghasilkan dan memacu adanya perubahan. Perubahan tersebut mencakup hampir dalam segala aspek dan pola hidup manusia, tidak terkecuali bagi kehidupan menggereja. Perlu adanya perubahan dalam kehidupan dan pembinaan kaum muda terutama di masa pandemi Covid-19. Apakah Gereja sungguh hadir bagi kehidupan umat? Apakah umat merasakan usaha Gereja untuk hadir dalam kehidupan umat? Apakah Gereja sungguh menanggapi perubahan? 
Dalam Konsili Vatikan II, Gereja menghadirkan diri sebagai communio, persekutuan umat Allah. Di tengah pandemi seperti ini, Gereja senantiasa berusaha untuk hadir dan melayani umat walaupun banyak kegiatan Gereja dibatasi dan perlu menerapkan protokol kesehatan guna memutus rantai penularan virus Covid-19. Gereja tidak meninggalkan umatnya dalam situasi pandemi Covid-19, Gereja tetap berupaya menjalin komunikasi dengan umat beriman dan Gereja senantiasa membuka diri atas setiap perubahan dan keadaan zaman.

Dalam Lumen Gentium art. 13, ditegaskan bahwa semua orang dipanggil kepada Umat Allah yang baru. Gereja yang merupakan umat Allah dengan iman akan Kristus tetap satu dan tunggal, harus berpegang teguh pada Sabda Allah, supaya terpenuhilah rencana kehendak Allah, yang pada awal mula menciptakan satu kodrat manusia, dan menetapkan untuk akhirnya menghimpun dan mempersatukan lagi anak-anak-Nya yang tersebar (lih. Yoh. 11:52). Berkat ciri Katolik itu, setiap bagian Gereja menyumbangkan kepunyaannya sendiri kepada bagian-bagian lainnya dan kepada seluruh Gereja. Berdasarkan ciri keKatolik annya, Konsili Vatikan II terus memberi perhatian pada kehidupan umat. "Konsili Vatikan II bertujuan untuk meningkatkan kehidupan Kristiani, menyesuaikan diri dalam menanggapi situasi aktual dunia, dan meneguhkan persatuan persaudaran dalam iman”. (Denny Firmanto, 2011: 218).

Peran Gereja dalam kehidupan masyarakat tidak dapat terelakkan karena menjadi suatu misi tersendiri bagi Gereja. "Kehadiran Gereja di tengah masyarakat bukan sekedar pilihan manasuka (optional), melainkan cita-cita yang harus diperjuangkan. Perjuangan itu merupakan bagian yang tak terpisahkan dari iman kepada Allah.” (2017:284). Dalam Patris Corde ditekankan kembali bahwa Penerimaan Yusuf mengundang kita untuk menerima orang lain sebagaimana mereka adanya, tanpa terkecuali, dengan memberi perhatian lebih pada yang lemah karena Allah memilih apa yang lemah. Dia adalah "Bapa bagi anak yatim dan Pelindung bagi para janda” (bdk. 1Kor 1:27), dan memerintahkan kita untuk mengasihi orang asing. (PC, 2020: 18). Maka dari itu, semua orang dipanggil termasuk kesatuan itu atau terarahkan kepadanya dengan aneka cara, baik kaum beriman Katolik , umat lainnya yang beriman akan Kristus, maupun semua orang tanpa kecuali, yang karena rahmat Allah dipanggil kepada keselamatan (Bdk. LG 13).

Penelitian ini lebih menekankan Gereja sebagai Umat Allah dan melihat sejauh mana usaha Gereja dalam membina iman umat mahasiswa Katolik rantau selama masa pandemi Covid-19, supaya tidak mengurangi antusiasme umat dalam merayakan imannya. Perhatian kepada kaum muda justru akan menjadi ujung tombak dalam perkembangan iman umat. Kaum muda sebagai generasi digital native yang merupakan pengguna media sosial turut menjadi audiens dalam paparan berita dan informasi terkait topik Covid-19 yang kemudian membuat 
seleksi informasi atasnya, (Purwaningtyas, 2020: 161). Pendekatan pada kaum muda terutama melalui skala kecil, seperti Mahasiswa Katolik yang merantau di Malang akan menjadi contoh bagaimana reaksi kehadiran Gereja yang mengumat ditanggapi kaum muda dalam menanggapi situasi Pandemi Covid-19.

Penelitian ini akan berangkat dari pertanyaan: Bagaimana pemahaman mahasiswa rantau mengenai pandemi virus Covid-19? Dimana sebagian besar mahasiswa yang merantau tinggal? Apakah mahasiswa Katolik yang merantau di Malang sungguh merasakan perasaan disapa oleh Gereja lokal atau justru mereka ditinggalkan? Bagaimana Gereja menanggapi situasi pandemi Covid-19? Apakah Gereja takut mengambil risiko dan justru menghindar? Apakah Gereja memilih untuk tertutup dalam keadaan umat? Lalu bagaimana Gereja menghadirkan diri sebagai Gereja Umat Allah bagi kaum muda yang mengalami kesulitan?

Sebagai objek kajian diambil dari mahasiswa Katolik yang merantau ke Malang dengan jumlah responden sebanyak 125 orang. Penelitian menggunakan metode studi literatur dan penyebaran angket atau kuesioner yang dibuat dalam bentuk google form. Penggunaan internet terutama media sosial menjadi sarana untuk melakukan penelitian, disamping memudahkan dalam penyebaran angket, juga dikarenakan media sosial lebih dekat dengan kaum muda.

Tujuan dari penelitian ini adalah untuk memberikan gambaran selama masa pandemi Covid-19, dengan berbagai anjuran dan pembatasan, terutama dalam kegiatan peribadatan. Mahasiswa Katolik yang merantau di Malang merasakan suatu usaha dari Gereja untuk mendekatkan diri dan ikut ambil bagian untuk bertanggungjawab atas hidup beriman umat dengan tetap memperhatikan protokol kesehatan yang ada.

\section{PEMBAHASAN}

\subsection{Gereja pada Saat Pandemi Covid-19}

Gereja disebut Katolik karena terbuka atau dapat diartikan untuk siapa saja, menyeluruh yang mana lengkap dan berkaitan dengan ajarannya dan tersebar ke seluruh dunia (Ignatius, 2013:18). Sejak zaman reformasi, sebutan Katolik secara khusus menunjuk pada umat Kristiani yang mengakui Paus sebagai pemimpin Gereja universal. Sementara itu Konsili Vatikan II menjelaskan sifat umum dan Katolik Gereja dalam Konstitusi Dogmatis tentang Gereja:

"Semua orang dipanggil kepada Umat Allah yang baru. Maka umat itu, yang tetap satu dan tunggal, harus disebarluaskan ke seluruh dunia dan melalui segala abad, supaya terpenuhilah rencana kehendak Allah, yang pada awal mula menciptakan satu kodrat manusia, dan menetapkan untuk akhirnya menghimpun dan mempersatukan lagi anak-anak-Nya yang tersebar (lih. Yoh. 11:52) (...) Sifat universal, yang menyemarakkan Umat Allah itu, merupakan karunia Tuhan sendiri. Karenanya Gereja yang Katolik secara tepat-guna dan tiada hentinya berusaha merangkum segenap 
umat manusia beserta segala harta-kekayaannya di bawah Kristus Kepala, dalam kesatuan Roh-Nya” (LG 13)

Kata Katolik tidak hanya menunjuk pada sekelompok orang yang terbatas, tapi juga kala Roh yang hadir dan berkarya di mana-mana serta menjiwai seluruh dunia dengan daya-Nya serta mengangkat kekayaan seluruh umat manusia (2013:19).

Awal tahun 2020 dunia dikagetkan dengan suatu bentuk virus baru yang dinamakan virus Corona atau dikenal dengan istilah (Covid-19). Virus ini menyerang sistem pernafasan pada manusia. Diketahui hal ini terjadi pertama kali di China, tepatnya November 2019 di kota Wuhan. Virus yang pada awalnya dianggap biasa dan tidak berbahaya, ternyata sangat berbahaya dan dapat membunuh manusia dengan tingkat penyebaran yang begitu cepat. Sampai saat ini belum diketahui penyebab dari virus Corona ini, tetapi ada pemberitaan bahwa virus ini disebarkan oleh hewan dan mampu menular dari satu spesies ke spesies lainnya, termasuk manusia. Wabah ini terus menyebar ke seluruh dunia dan memaksa banyak negara menerapkan sistem lockdown (suatu tindakan yang diambil untuk secara sementara waktu menutup ataupun mencegah orang keluar dari suatu tempat ataupun wilayah dikarenakan adanya suatu bahaya akan virus yang dapat menular dan kemudian menyebar).

Keadaan semacam itu memaksa dunia untuk melakukan isolasi maupun karantina bagi warganya yang tertular maupun terdampak oleh virus ini. Kegiatan-kegiatan yang biasa dilakukan di luar rumah terpaksa dibatasi untuk sementara waktu, fasilitas-fasilitas umum bahkan ditutup untuk mencegah penularan dari virus ini. Hal ini juga berpengaruh dalam kehidupan Gereja terutama pelayanannya terhadap umat beriman.

\subsection{Pandangan Agustinus dari Hippo (354-430): Penderitaan adalah Keindahan}

Gereja dalam situasi pandemi Covid-19 mengalami banyak hal baru, terutama dalam berpastoral ataupun pelayanan terhadap umat. Situasi yang serba tidak pasti dan mencemaskan, terkadang terkesan menakutkan dan bisa membuat umat masuk dalam masa pencobaan ataupun penderitaan. Gereja diajak berefleksi bersama Santo Agustinus, bagaimana memaknai suatu penderitaan, pencobaan, persoalan maupun masalah dibawa kepada suatu yang lebih luas dan tinggi, yang mana merupakan suatu keindahan dari suatu misteri karya penyelamatan Allah.

Agustinus dari Hippo adalah seorang pemikir Kristen pada abad ke-4. Aliran filsafat yang dominan pada masanya adalah filsafat Stoa dan Neoplatonisme, keduanya berangkat dari suatu pengandaian akan adanya sebuah dunia yang teratur, sebuah kosmos yang dikuasi oleh sebuah logos yang merencanakan dan menyelenggarakan sesuatu, sehingga tidak akan ada sesuatupun yang terjadi, yang 
tidak direncanakan. Kalau sesuatu itu direncanakan, maka akan mempunyai makna untuk keseluruhan. Di dalam pengaturan logos ini, kematian dan kehidupan, badan dan penyakit, kebaikan dan keburukan saling mempengaruhi. Karena logos yang mengatur semuanya bersifat ilahi, maka seluruh kenyataan yang ada pun terhimpun dalam sebuah keharmonisan ilahi.

Sebagaimana suatu lukisan yang baik memiliki juga sisi yang kurang terang pada tempat yang sesuai, demikian juga segala sesuatu yang ada di dalam dunia. Kalau orang memperhatikan keseluruhannya, maka dunia ini indah dan harmonis, juga dengan dosa dan penderitaan di dalamnya. Memang, jika dosa dan penderitaan itu diperhatikan secara khusus, maka mereka akan merusakkan lukisan tersebut. Namun, dalam satu keseluruhan, adanya dosa dan penderitaan justru memperindah dan memberi warna kepada kehidupan.

Konsekuensinya dari pandangan seperti ini adalah bahwa sesuatu yang untuk sementara dialami sebagai sesuatu yang buruk di dunia tidak dapat membatalkan aturan kesatuan yang menjadi dasarnya. Sebaliknya, keagungan aturan yang mengatur seluruh dunia menjadi lebih bercahaya, apabila di dalamnya ada keburukan yang terabdi pada yang baik. Kalau demikian yang buruk itu adalah bagian dari sebuah keteraturan yang lebih tinggi, walaupun kita tidak selalu mudah memahami dan melihatnya. Penderitaan yang kita alami di dunia ini mempunyai makna, sebab dia sudah direncanakan, dan karena dalam perencanaan itu dia akan berguna bagi sesuatu yang belum kita kenal sebelumnya (Paul, 2006:91-92). Gereja dalam perjalanan sepanjang sejarah berusaha secara konsisten untuk berkomitmen dalam mendampingi dan mengembangkan iman umat.

\subsection{Gereja dalam Misi: Sakramen Universal Keselamatan}

Komitmen Gereja dalam pelayanannya terus hadir dalam perjalanan sepanjang sejarah hidup manusia lewat Gereja yang bermisi. Misi Gereja tidak terlepas dari pada rencana keselamatan Allah dalam sejarah kehidupan manusia yang dimulai sejak awal mula, yakni sejak Allah menciptakan dunia dan segala isinya. Dalam artikel kedua dari dokumen Ad Gentes diutarakan suatu asas mengenai rencana Bapa yang bersumber dari refleksi Gereja atas karya misi yang diterimanya. Dikatakan demikian (AG art. 2):

Adapun rencana itu bersumber pada "cinta” atau "kasih asali” Allah Bapa. Dialah Asal tanpa Asal; dari pada-Nyalah Putera lahir dan Roh Kudus berasal melalui Putera. Karena kemurahan-Nya yang melimpah dan berbelaskasihan Bapa dengan bebas menciptakan kita serta penuh kasih memanggil kita, untuk bersama dengan-Nya ikut menikmati kehidupan dan kemuliaan-Nya. Dengan murah hati Ia melimpahkan dan tiada hentinya mencurahkan kebaikan ilahi-Nya, sehingga Dia yang menciptakan segalanya, akhirnya akan menjadi "semuanya dalam segalanya" (1 Kor. 15:28), dengan sekaligus mewujudkan kemuliaan-Nya dan kebahagiaan kita. Tetapi 
Allah berkenan memanggil orang-orang bukan hanya satu per satu, tanpa hubungan mana pun satu dengan yang lain, untuk ikut serta dalam kehidupan-Nya. Melainkan Ia berkenan menghimpun mereka menjadi umat, supaya di situ para putera-Nya, yang semula tercerai-berai, dikumpulkan menjadi satu (lih. Yoh. 11:52).

Di sini, Gereja melihat bahwa karya misi bermula daripada "cinta" atau "kasih asali” Allah Bapa. Cinta Bapa inilah yang membuat Bapa secara bebas menciptakan manusia dan memanggil manusia untuk hidup bersama Allah dalam kemuliaan-Nya. Bapa tidak hanya memanggil satu persatu manusia untuk menerima cinta dari Allah, melainkan menghendaki agar semua umat manusia berhimpun menjadi satu untuk mengalami cinta Allah tersebut.

Panggilan Allah ini dalam sejarah umat manusia kerap kali dihalangi oleh dosa dan kelalaian manusia yang membuat manusia tidak mampu untuk menjawab panggilan dari Allah tersebut. Hal ini banyak dijumpai dalam pengalaman sejarah bangsa Israel dan relasinya dengan Allah yang termuat dalam Kitab Suci. Peter Aman (2016:148-150) mencoba menyimpulkan definisi dosa yang terdapat dalam alam pemikiran Perjanjian Lama, di mana dosa dilihat sebagai perlawanan atau pemberontakan terhadap Allah. Meski demikian, dosa itu tidak melukai atau merusak Allah pada diri-Nya, tetapi sebaliknya merusak manusia berdosa itu sendiri (bdk. Ayb. 35:6; Yes. 59:1-2; Yer. 7:8.19). Aman juga menambahkan bahwa dosa merusak gambar Allah, dalam diri manusia, karena dengan berdosa manusia menolak untuk dikasihi Allah. Aman juga mengutip Stanislaus Lyonet yang mengemukakan demikian: “...kalaupun dosa itu mengena pada Allah maka yang dimaksud bahwa cinta Allah tidak dibalas dengan cinta (amor non amatur). Dalam tradisi Katolik , Agustinus turut menyumbangkan pemikirannya mengenai dosa. Dosa didefinisikan sebagai “aversio a Deo, conversio ad creatur"' yakni berbalik dari Allah dan mengarahkan kepada ciptaan (Aman, 2016:151).

Dosa menjauhkan manusia dari Allah. Tidak hanya itu, Paulus dalam suratnya kepada orang Roma berkata demikian: "Sebab upah dosa ialah maut...” (Rm. 6:23). Maut menjadi jurang yang tidak terseberangi antara Allah dan manusia berdosa yang menyebabkan manusia tidak dapat menikmati kehidupan kekal bersama dengan Allah (bdk. Luk. 16:26). Untuk menyelamatkan manusia dari bahaya dosa, maka Allah mengutus Putera-Nya untuk datang ke dalam sejarah hidup umat manusia dan menjadi perantara yang merajut kembali relasi antara Allah dan manusia yang telah rusak oleh karena dosa dan kelalaian manusia. Ad Gentes art. 3 mengungkapkan demikian:

Rencana Allah untuk menyelamatkan seluruh umat manusia itu terlaksana bukan saja seolah-olah secara tersembunyi dalam jiwa manusia, atau pun melalui usaha-usaha mereka, juga yang bersifat keagamaan, [...] Namun untuk membangun perdamaian atau persekutuan dengan diri-Nya dan untuk menghimpun masyarakat 
persaudaraan antarmanusia pendosa, Allah telah memutuskan untuk secara baru dan definitif memasuki sejarah bangsa manusia dengan mengutus Putera-Nya dalam daging kita. Allah bermaksud merebut manusia dari kuasa kegelapan dan setan (lih. Kol. 1:13; Kis. 10:38) melalui Dia, dan dalam Dia mendamaikan dunia dengan diri-Nya (lih. 2 Kor. 5:19). Maka Allah menetapkan Putera-Nya, yakni Perantara-Nya dalam menciptakan alam semesta, menjadi ahli waris segala-sesuatu, untuk membaharui semuanya dalam Dia (lih. Ef. 1:10). Sebab Kristus Yesus diutus ke dunia sebagai Perantara sejati antara Allah dan manusia.

Sabda Allah telah menjadi manusia dan telah tinggal di antara manusia (bdk. Yoh.1:14). Melalui misteri inkarnasi ini, Yesus, Sang Putera Tunggal Allah mewujudnyatakan rencana dan karya keselamatan Allah bagi manusia. Tindakan Allah tersebut pada akhirnya berpuncak pada peristiwa sengsara, wafat dan kematian Yesus. Jon Sobrino, dalam buku yang berjudul Christology at the Crossroad (1994:xvii), menggarisbawahi peristiwa ini dengan suatu ungkapan: "Sin is that which brought death to the Son of God" (dosa yang membawa kematian bagi Anak Allah).

Misi berasal dari kata bahasa Latin yakni mittere yang berarti mengirim atau mengutus. Menurut Guiseppe Buono (2004:55), kata misi mengekspresikan dua realitas, yakni: "the sending of a person by he who has the power to send" dan "specific task that the sender entrust to the person sent". Di samping itu, konsep dari misi menurut Buono mengekspresikan realitas yang berbeda, yakni: "the nature of the task entrusted by the sender to the person sent, the aim of the mission entrusted dan the receivers of the mission”. Dalam kaitannya dengan misi Gereja, dokumen Ad Gentes pada bagian pendahuluan (art.1) menyebutkan bahwa Gereja diutus oleh Allah kepada para bangsa untuk menjadi "sakramen universal keselamatan”. Jika ditelaah sesuai dengan paradigma Buono di atas, Allah menjadi pihak yang mengutus Gereja dengan memberi kuasa kepada Gereja untuk tugas perutusan ini dan Gereja mendapatkan tugas spesifik yakni untuk menjadi sakramen universal keselamatan. Hal yang kemudian menjadi poin penting untuk dicermati ialah tujuan dari misi Gereja yakni Gereja sebagai tanda keselamatan dan penerima misi ini, yakni para bangsa. Misi ini tentu mengandung karakteristik atau kualitas yang tinggi dan bersifat ilahi.

\subsection{Perutusan Gereja: Pelayanan Kaum Muda}

Karya keselamatan Allah terus bertumbuh dan berkembang dalam sejarah hidup umat manusia. Kehadiran Yesus di dunia merupakan suatu bentuk pemenuhan rencana keselamatan Allah yang sudah datang dan akan mencapai pemenuhannya pada akhir jaman. Selama menunggu kepenuhan, yakni akhir jaman, Gereja senantiasa melakukan misi yang Yesus percayakan kepada para 
murid yakni untuk mewartakan Injil ke seluruh dunia, seperti yang dicatat oleh penginjil Markus:

"Pergilah ke seluruh dunia, beritakanlah Injil kepada segala makhluk. ${ }^{16}$ Siapa yang percaya dan dibaptis akan diselamatkan, tetapi siapa yang tidak percaya akan dihukum. ${ }^{17}$ Tanda-tanda ini akan menyertai orang-orang yang percaya: mereka akan mengusir setan-setan demi nama-Ku, mereka akan berbicara dalam bahasa-bahasa yang baru bagi mereka, ${ }^{18}$ mereka akan memegang ular, dan sekalipun mereka minum racun maut, mereka tidak akan mendapat celaka; mereka akan meletakkan tangannya atas orang sakit, dan orang itu akan sembuh” (Mrk. 16:15-18) Mrk. 16:15-18.

Dalam misi yang disampaikan oleh Yesus, para murid bukan hanya sekadar menerima perutusan, tetapi mereka juga dibekali dengan berbagai macam kemampuan atau kecakapan sebagai pengikut Kristus. Jika dilihat dari konsep misi menurut Buono (berkenaan dengan aim, recievers dan nature), misi Yesus dalam kutipan ayat di atas mengekspresikan tujuan dari misi, yakni untuk "pergi ke seluruh dunia” dan "memberitakan Injil” di mana pihak yang dituju adalah "semua makhluk”. Sebagai tindak lanjut dari rencana Allah, misi yang Yesus berikan memiliki suatu kualitas yang ilahi di dalamnya.

Lalu pertanyaan yang mungkin akan timbul kemudian ialah: “apa isi pokok dari Injil (misi Yesus) yang harus diberitakan ke seluruh dunia itu?” Hal itu agaknya ditunjukan dalam visi misi Yesus yang disampaikan ketika Yesus membaca kitab nabi Yesaya saat berada di rumah ibadat (bdk. Luk. 4:18-19), yakni dalam Yesaya 61:1-2. Secara lebih gamblang, misi Yesus dinyatakan dalam seruan yang awalnya kerap diserukan oleh Yohanes, yakni: "Bertobatlah, sebab Kerajaan Sorga sudah dekat!” (Mat. 3:2; 4:17; Mrk. 1:15). Kerajaan Allah menjadi pusat pewartaan Yesus di dunia.

Yesus memang banyak berbicara mengenai Kerajaan Allah, utamanya dalam berbagai perumpamaan yang disampaikan Yesus dalam injil Sinoptik. Kerajaan Allah yang diwartakan oleh Yesus dalam berbagai perumpamaan memang tidak menunjuk pada suatu tempat tertentu, melainkan lebih merujuk pada suatu situasi atau kondisi tertentu. Jon Sobrino (1994:42-43) dalam bukunya mengatakan demikian:

Our term "kingdom of God" may tend to support a static situation which has no place in the original Hebrew expression (malkuth Yahweh). The latter suggest two basic notions: (1) God reign with acts of power, (2) in order to establish or modify the order of things. The real emphasis is on the first verb and so we would do better to talk about the sovereign "reign" of God rather than about his "kingdom".

Penekanan yang diberikan di sini ialah pemerintahan kedaulatan Allah (situasi) dan bukan kerajaan (tempat tertentu). Dalam setiap pengajaran dan 
tindakan-Nya, Yesus senantiasa berorientasi pada Kerajaan Allah beserta dengan segala sifat-sifat yang dimilikinya. Segala sifat yang ada memperoleh suatu dasar yang kokoh di dalam suatu prinsip yang disebut sebagai "Hukum Cinta Kasih" (bdk. Mat. 22:36-39; Mrk. 12:28-31). Hukum ini pada akhirnya mengerucut pada pemberian cinta Allah yang sehabis-habisnya (bdk. Yoh. 15:13) dalam Jalan Salib untuk membebaskan manusia dari dosa (bdk. Mat. 26:28). Maka dari itu, misi yang Yesus berikan kepada para murid-Nya ialah mewartakan kedatangan Kerajaan Allah yang adalah Kerajaan Cinta Kasih. Para murid menjadi contoh kebutuhan Gereja akan peran kaum muda. Kaum muda menjadi masa depan bagi generasi ke depan. Gereja dalam Redemptoris Missio art. 80, mengatakan:

"Kami meminta kepada orang-orang muda itu sendiri untuk mendengarkan sabda-sabda Kristus karena Dia berkata kepada mereka apa yang dulu pernah Ia sekali mengatakannya kepada Simon Petrus dan kepada Andreas di tepi danau itu: "Ikutlah Aku, dan kamu akan kujadikan penjala manusia”. (Mt 4:19). Hendaknya mereka memiliki keberanian untuk menjawab sebagaimana dilakukan oleh Yesaya: "Ini aku, Tuhan! Aku siap! Utuslah aku!" (bdk. Yes 6:8). Di hadapan mereka akan terbentanglah suatu kehidupan yang mengagumkan, dan mereka kan mengetahui kegembiraan nan asli dalam memberitakan "Khabar Gembira" kepada saudara-saudara dan saudari-saudari yang akan mereka tuntun pada jalan keselamatan”.

Perutusan sesungguhnya Gereja bagi kaum muda ditunjukan dalam Dokumen Akhir dari Sidang Umum Biasa XV Sinode Para Uskup berkaitan tentang Orang Muda, Iman, Dan Penegasan Panggilan no. 54:

"Orang-orang muda Katolik bukan sekedar objek karya pastoral, melainkan anggota hidup dari tubuh Gereja yang satu, mereka telah dibaptis dan di dalam mereka Roh Tuhan hidup dan berkarya. Mereka ikut serta memperkaya keberadaan Gereja dan bukan sekadar apa yang dilakukan Gereja. Mereka adalah masa sekarang dan bukan hanya masa depan Gereja. Orang muda adalah pelaku utama dari banyak aktivitas gerejawi, di mana mereka menawarkan pelayanan mereka secara murah hati, khususnya dengan animasi katekese dan liturgi, perhatian terhadap mereka yang terkecil, relawan untuk orang-orang miskin. Gerakan-gerakan, perkumpulan-perkumpulan, serta kongregasi-kongregasi religius juga menawarkan kepada orang-orang muda peluang-peluang untuk berkomitmen dan bertanggung jawab. Kadang-kadang, kesiapsediaan orang-orang muda berhadapan dengan autoritarianisme dan ketidakpercayaan kaum dewasa dan para gembala, yang tidak cukup mengakui kreativitas dan usaha keras mereka untuk berbagi tanggung jawab”.

Dalam hidup menggereja, peran kaum muda memberikan angin segar, karena Gereja tidak akan berkembang dan bertumbuh tanpa kehadiran kaum muda 
yang berpartisipasi terutama di masa pandemi Covid-19 seperti ini. Gereja perlu memperhatikan kaum muda terutama bagi kaum muda yang berada di tanah perantauan.

\subsection{Hasil Penelitian}

Menurut Shelton Charles M. SJ, rentang usia kaum muda ialah 15-24 tahun (Charles M., 1987:9). Dalam usia ini, kaum muda mempunyai karakter yang siap untuk menerima segala tempaan dan tantangan kehidupan. Gereja sungguh diperlukan dan dirasakan kehadirannya oleh seluruh kaum muda, maka pada akhirnya peneliti membuat riset yang sederhana (docs.google.com) yang akan membahas tentang, apakah kaum muda sungguh merasakan bahwa Gereja hadir dan menyapa mereka sebagai umat beriman, terutama bagi mahasiswa Katolik yang merantau di Malang?, serta terdapat beberapa hasil penelitian yang dapat disimpulkan.

Berdasarkan temuan dari penyebaran angket, peneliti mencoba merangkum situasi kaum muda terutama bagi mahasiswa Katolik yang merantau ke Malang dan terutama dalam kehidupan menggereja selama masa pandemi Covid-19. Mayoritas 119 responden atau 95,2\% merupakan mahasiswa yang menempuh pendidikannya di kampus wilayah Malang dan merupakan seorang perantau, menyatakan diri “iya” sebagai Mahasiswa yang merantau ke Malang, sedangkan terdapat 6 Responden atau 4,8\% yang menyatakan "tidak" sebagai mahasiswa yang merantau ke Malang.

Sebagai mahasiswa yang merantau di Kota Malang sebanyak 94 responden atau $75,2 \%$ bertempat tinggal di kontrakan atau kos, sebanyak 23 responden atau 18,4 tinggal di Asrama ataupun sebuah komunitas, dan sebanyak 8 responden atau 6,4\% tinggal di rumah keluarga.

Dalam pemahaman mahasiswa akan situasi yang dialami di masa pandemi Covid-19 bahwa 47 responden atau 37,6\% menyatakan sangat paham dengan persoalan pandemi Covid-19, terdapat 77 responden atau 61,6\% menyatakan paham dan sebanyak 1 responden atau 0,8\% yang menyatakan kurang paham, sedangkan untuk pernyataan tidak paham tidak ada. Persoalan pandemi Covid-19 membuat pemerintah menetapkan protokol kesehatan untuk menjaga jarak, menggunakan hand sanitizer, dan selalu menggunakan masker guna meminimalisir penyebaran Covid-19.

Berkaitan dengan kehidupan mahasiswa dalam menerapkan protokol kesehatan, bahwa mahasiswa Katolik yang merantau ke Malang menyatakan "iya, saya paham dan menjalankannya” sebanyak 109 responden atau 87,2\%. Kemudian sebanyak 16 responden atau 12,8\% yang menyatakan “iya, saya paham tetapi kurang menjalankannya”, sedangkan untuk pernyataan "tidak, saya tidak paham 
dan tidak menjalankannya” tidak ada. Mahasiswa menunjukkan bahwa penerapan protokol kesehatan ini penting.

Dalam menanggapi situasi pandemi Covid-19 Gereja juga mengikuti anjuran pemerintah untuk menerapkan protokol kesehatan ditunjukan dengan berdasarkan hasil penelitian yang didapat, bahwa sebanyak 122 responden atau 97,6\% menyatakan bahwa Gereja "selalu” menerapkan protokol kesehatan, dan sebanyak 3 responden atau 2,4\% menyakatan bahwa Gereja "beberapa kali” menerapkan protokol kesehatan. Hal tersebut berdampak pada pembatasan aktifitas dalam kehidupan menggereja secara fisik dengan datang ke Gereja. Pembatasan semacam ini cukup dirasakan oleh mahasiswa yang merantau di Kota Malang dikarenakan adanya pembatasan. Paroki maupun stasi yang biasanya dibuka untuk umum, menjadi hanya diperuntukkan bagi umat paroki atau Gereja lokal tersebut.

Berdasarkan data yang didapatkan terdapat 19 responden atau 15,2\% menyatakan "sangat kesulitan”, 39 responden menyatakan "kesulitan” dan 67 responden atau 53,6\% menyatakan "tidak kesulitan” dalam mengikuti perayaan Ekaristi maupun kegiatan di Gereja, lantaran bukan berasal dari paroki atau Gereja tersebut. Kesulitan akan pembatasan kehidupan menggereja secara fisik tidak membuat Gereja diam menanggapi situasi zaman.

Gereja terus mempelajari situasi dan mencoba membuat langkah-langkah baru terutama dalam pelayanan untuk mengembangkan hidup beriman umat, ditunjukan dengan terdapat 83 responden atau 66,4\% menyatakan bahwa Gereja "selalu" mengusahakan langkah-langkah baru untuk membina iman umat, kemudian 25 responden atau 20\% menyatakan "beberapa kali”, 15 Responden atau 12\% menyatakan “jarang” dan 2 responden atau 1,6\% “tidak pernah”. Gereja seperti tidak tinggal diam melihat fenomena yang terjadi dalam masa pandemi Covid-19 ini, tetapi terus berusaha untuk dapat menyapa umat. Pembatasan ruang untuk berkumpul secara fisik akan menghambat adanya komunikasi secara langsung, maka sejauh mana Gereja sungguh beraksi dalam mengusahakan pembinaan hidup beriman umat secara langung maupun tidak langsung.

Dalam pertanyaan yang disebarkan kepada mahasiswa Katolik rantau, berbunyi “Apakah saya merasakan bahwa Gereja di masa pandemi Covid-19 ini tetap menyapa dan sungguh hadir dalam pembinaan hidup beriman saya sebagai mahasiswa Katolik yang merantau di Malang ini?”, didapatkan sejumlah 81 responden atau 64,8\% menyatakan bahwa mahasiswa "selalu" merasakan bahwa Gereja tetap menyapa dan sungguh hadir dalam pembinaan iman, 30 responden atau 24\% menyatakan "beberapa kali”, 12 responden atau 9,6\% menyatakan “jarang” dan 2 responden atau 1,6\% menyatakan "tidak pernah”.

Dalam pertanyaan “Apa harapanku sebagai mahasiswa Katolik yang merantau di Malang selama Pandemi Covid-19 bagi kehidupan Gereja?”, terdapat 125 jawaban yang apabila dirangkum sebagian besar berharap supaya pandemi 
segera berakhir agar mahasiswa Katolik yang merantau di Malang dapat kembali mengikuti kegiatan Gereja maupun Perayaan Ekaristi dalam keadaan normal dan tidak ada lagi pembatasan, terdapat pertemuan bersama, doa bersama dan berbagai kegiatan Gereja yang selalu diusahakan bersama.

\subsection{Pembahasan}

Agama adalah sesuatu yang bersifat pribadi dan secara umum disegani manusia dikarenakan penghayatan yang bersifat pribadi (Bernard, 2013:2). Hal ini membuat agama dalam kepercayaan dan tradisinya dapat membentuk cara pandang seseorang tentang dunia, bahkan agama memiliki simbol yang membantu dalam berelasi dengan yang suci. Pengalaman keagamaan merujuk pada semua pengalaman subjektif individu dalam berhungan dengan yang suci (2013:15) dan juga membawa masyarakat pada kesadaran akan keanggotaan dalam kelompok pemeluk (2013:17).

Masyarakat modern yang adalah masyarakat sekuler, tidak lepas dengan adanya agama yang memberikan peran dalam struktur institusional sosial yang penting. Agama hadir sebagai pelengkap dan kerap menentukan kehidupan sosial masyarakat terutama dalam suatu sistem sosial yang ada, berlaku maupun saling tergantung satu dengan lainnya, sehingga apabila terjadi perubahan dari salah satu bagian dapat menimbulkan dampak pada keseluruhan sistem sosial dalam masyarakat.

Agama sendiri memberi penekanan pada sistem kepercaayaan yang ditemukan dalam kehidupan harian masyarakat, termasuk dalam membantu masyarakat untuk memberi arti, makna dan menginterpretasikan setiap pengalaman dan peristiwa yang dialami. Para ahli ilmu pengetahuan juga memanfaatkan pendekatan sosiologi dalam melihat tentang tatanan sosial dalam masyarakat agama. Agama cukup menjadi sarana pemersatu dalam masyarakat, baik dalam aspirasi, mindset maupun pola pikir manusia dalam kehidupan bersama. Setiap pelaku dalam interaksi sosial itu sudah dari sananya termasuk dalam struktur sosial, norma dan nilai-nilai kultural tertentu yang sudah melekat dan menempel pada hidup setiap pelaku sejak kelahirannya (Sermada Kelen, 2017:117).

Agama membantu mengembangkan moralitas yang memuliakan, menaikkan derajat serta membuat manusia menjadi lebih beradab, sehingga dapat dijadikan sebagai sumber tatanan masyarakat dan perdamaian batin individu yang menganut dan memeluk agama tertentu. Di sisi lain, agama dituduh sebagai penghambat kemajuan, mempertinggi fanatisme bahkan memiliki sifat yang intoleran, menciptakan permusuhan, percaya akan tahayul, menghasilkan bid'ah, dan lain-lain. Agama diposisikan hanya sebagai obat penenang ataupun sebagai candu bagi masyarakat yang membutuhkan sensasi bahagia, ceria ataupun lepas dari derita secara sementara. Hal ini juga ditunjukan dalam "Menara Babel” yang 
menjadi salah satu bukti kemahakuasaan manusia. Manusia yang memiliki pengetahuan yang baik dan yang jahat, kini bisa merencanakan apa saja. Apa yang direncanakan bukan lagi hal yang mustahil untuk diwujudkan. Inilah alasan mengapa Allah mengacaukan rencana mereka (Tri Wardoyo, 2019: 195-196).

Gereja sering juga dikaitan dengan agama, namun Gereja sendiri juga mengandung arti umat Allah. Gereja mengembangkan iman akan Kristus yang kemudian disebut sebagai iman Kristiani. Iman Kristiani berkembang dalam kehidupan beriman umat dengan bantuan katekese. Katekese pertama dimulai dari keluarga. Keluarga Katolik membimbing dan mengajarkan pengetahuan untuk beriman kepada anak-anak, namun tidak bisa dipungkiri kepada mereka yang kemudian untuk percaya. Baptis dewasa maupun baptis bayi harus mendapatkan porsi yang sesuai dalam pengembangan iman mereka. Katekese dalam perkembangan Gereja memiliki cara dan model yang terus menerus diperbaharui dan disesuaikan dengan kebutuhan zaman, berbeda dalam cara namun sama dalam pewartaan iman. Hal ini berlaku bagi siapa saja, tanpa terkecuali bagi mahasiswa Katolik yang merantau ke Malang.

Penegasan atas responden seorang mahasiswa perlu diusahakan berdasarkan pertanyaan yang diajukan dalam penelitian "Apakah saya termasuk mahasiswa yang merantau ke Malang?” didapatkan terdapat 119 respendon atau 95,2\% yang menyatakan diri "iya” bahwa mereka adalah mahasiswa yang merantau ke Malang, sedangkan terdapat 6 responden atau 4,8\% yang menyatakan "tidak" sebagai mahasiswa yang merantau ke Malang. Itu artinya bahwa mahasiswa yang mengisi kuisioner dalam penelitian ini tidak semuanya merupakan mahasiswa yang merantau di Malang, kemungkinan mereka adalah mahasiswa yang berasal atau tinggal di Malang ataupun ditemukan kemungkinan lain bahwa mereka sudah tidak menjadi mahasiswa lagi namun masih tinggal di Malang. Pertanyaan ini diajukan pertama dalam kuesioner guna menegaskan kembali apakah benar responden dalam penelitian ini sungguh seorang mahasiswa Katolik yang merantau ke Malang dan berdasarkan hasilnya 95,2\% artinya penelitian masih dapat dilanjutkan dan dipertangungjawabkan.

Sebagian besar mahasiswa Katolik yang merantau di Kota Malang tinggal di kontrakan atau kos berdasarkan data yang ditunjukan dengan angka 94 responden atau 75,2\% dari 125 responden yang ada. Kemudian sebanyak 23 responden atau 18,4\% tinggal di Asrama ataupun sebuah komunitas, dan sebanyak 8 responden atau 6,4\% tinggal di rumah keluarga. Kehadiran mereka bagi Gereja dianggap sebagai perantau yang tidak termasuk dalam keanggotaan dalam paroki lokal, sehingga kerap kali mereka tidak ada catatan administrasi di paroki ataupun Gereja lokal tertentu. Selama pandemi Covid-19 pendaftaran untuk mengikuti kegiatan-kegiatan Gereja maupun Ekaristi lebih ditujukan kepada anggota Gereja lokal atau paroki berdasarkan data administrasi, sehingga kehadiran para perantau 
yang hendak mengikuti perayaan Ekaristi maupun kegiatan-kegiatan Gereja menjadi "kurang diperhatikan”. Secara administrasi Gereja, mahasiswa Katolik yang merantau ke Malang tidak terdaftar dalam anggota umat suatu paroki tertentu untuk mengikuti perayaan Ekaristi maupun kegiatan-kegiatan Gereja tanpa meninggalkan prioritas paroki pada umat Gereja lokal tersebut.

Virus corona merupakan virus yang mematikan yang dapat ditularkan dengan mudah lewat interaksi langsung dengan penderita. Pemahaman tentang virus corona bagi mahasiswa Katolik yang merantau di Malang dinyatakan dalam data bahwa 47 responden atau 37,6\% menyatakan sangat paham dengan persoalan pandemi Covid-19, kemudian terdapat 77 responden atau $61,6 \%$ menyatakan paham dan sebanyak 1 responden atau 0,8\% yang menyatakan kurang paham, sedangkan untuk pernyataan tidak paham tidak ada. Artinya, sebagian besar mahasiswa Katolik yang merantau ke Malang menyadari akan bahaya yang disebabkan oleh virus corona pada kesehatan. Mahasiswa harus berusaha mencegah penyebaran maupun penularan virus dalam kehidupan sehari-hari.

Pemahaman akan bahaya virus corona perlu diusahakan dalam tindakan ataupun usaha melakukan tindakan pencegahan. Mahasiswa perlu tahu secara teori dan mau mengusahakan diri taat pada protokol kesehatan dengan ditunjukan yang menyatakan bahwa "iya, saya paham dan menjalankannya” sebanyak 109 responden atau 87,2\%. Kemudian sebanyak 16 responden atau 12,8\% yang menyatakan "iya, saya paham tetapi kurang menjalankannya”, sedangkan untuk pernyataan "tidak, saya tidak paham dan tidak menjalankannya" tidak ada. Itu artinya masih cukup banyak mahasiswa yang secara sadar berkomitmen untuk mengusahakan diri taat dan menjalankan anjuran-anjuran pemerintah untuk menerapkan protokol kesehatan serta ada beberapa orang yang secara sadar tahu tetapi kurang memiliki komitmen untuk mengusahakannya dalam hidup sendiri, sehingga tidak membahayakan orang lain. Kesadaran diri akan bahaya dan mengusahakan diri untuk tidak membahayakan orang lain adalah bentuk kepedulian dan solidaritas terhadap saudara yang terdampak virus korona. Kesadaran akan solidaritas dan tidak membahayakan orang lain masih menjadi tugas rumah bagi orang muda yang dalam keseharian tahu tetapi apatis untuk melakukan. Mahasiswa masih memiliki kecenderungan paham akan bahaya virus corona dan pencegahannya, namun kurang mengerti dalam menjalankan dan mengusahakan dalam hidup harian.

Gereja yang ada di dunia membuka diri pada perubahan dan situasi zaman terutama dalam situasi pandemi hal tampak bahwa sebanyak 122 responden atau 97,6\% menyatakan bahwa Gereja "selalu” menerapkan Protokol kesehatan, dan sebanyak 3 responden atau 2,4\% menyakatan bahwa Gereja "beberapa kali” menerapkan protokol kesehatan. Pernyataan bahwa Gereja “jarang” dan "tidak pernah” menerapkan protokol kesehatan tidak ada. Gereja sejak setelah Konsili 
Vatikan II tetap memegang semangat Aggiornamento atau memperbaharui diri dengan terbuka pada situasi zaman terutama dalam pandemi virus corona, Gereja sungguh menunjukkan semangat memperbaharui diri, tidak menutup diri pada perubahan dan terus mencoba untuk menjawab kebutuhan zaman. Gereja akan senantiasa memperbaharui diri dan menyesuaikan kebutuhan zaman tanpa menghapuskan inti iman, sehingga bentuk-bentuk karya pastoral, pelayanan sakramental dan kategorial akan senantiasa berkembang.

Komunikasi iman berangkat dari iman yang meresap dalam kehidupan harian dalam terang injil yang membawa orang bertobat dan semakin menyadari kehadiran Allah. Kepenuhan beriman dalam pengamalan cinta kasih yang dikukuhkan dalam hidup kristiani setiap hari. Persatuan dalam Kristus yang menjemaat dalam perwujudan tugas gerejani setempat akan mengkokohkan Gereja Katolik yang berarti universal dalam kesaksian tentang Kristus di tengah masyarakat. Katekese umat memperhatikan setiap umat masing-masing yang bersifat personal guna menegaskan tujuan sebagai Gereja di tengah dunia yang senada dalam Injil Matius bahwa umat harus menjadi garam dan terang dunia (bdk. Mat 5:13-14)

Kesadaran akan katekese dalam diri umat membawa pada pemanusiaan Kristiani dalam penempatan pengalaman religus ke hidup konkret masing-masing umat, sehingga penafsiran dalam kehidupan harian sejalan dengan sejarah karya keselamatan Allah dalam manusia yang berinkarnasi ke dunia, dilahirkan, menderita, wafat dan bangkit pada hari ketiga. Keterbukaan diri akan kehadiran Allah membawa pada pertobatan yang membawa pada penghayatan hidup yang profan dan penuh dosa ke hidup yang menjadi sarana perjumpaan dengan Allah. Kesadaran akan pengalaman mengalami dan menyadari karunia Allah dalam kehidupan sehari-hari dalam iman, harapan dan kasih membawa katekese yang berasal dari umat, oleh umat dan ditujukan kepada umat menjadi sungguh nyata dalam berkatekese kepada umat.

Berdasarkan hasil yang didapatkan bahwa sebanyak 19 responden atau 15,2\% menyatakan "sangat kesulitan”, 39 responden menyatakan "kesulitan” dan 67 responden atau 53,6\% menyatakan "tidak kesulitan” dalam mengikuti perayaan Ekaristi maupun kegiatan di Gereja, lantaran bukan berasal dari paroki atau Gereja tersebut. Mahasiswa Katolik yang merantau merasakan adanya kesulitan dalam menghadirkan diri dalam kegiatan-kegiatan kegerejaan, walaupun juga terdapat sebagian besar mahasiswa yang terfasilitasi untuk bergabung dalam Perayaan Ekaristi dan kegiatan-kegiatan Gereja. Gereja tentu tidak boleh secara cepat menyimpulkan bahwa keberadaan mahasiswa yang merantau ke Malang cukup mendapatkan pelayanan dalam kehidupan Gereja. Gereja tidak melihat dalam jumlah saja tetapi juga kualitas, namun juga bukan hanya mengusahakan kualitas beberapa umat tanpa memperhatikan mayoritas umat yang tertinggal dan tidak 
terlayani dalam kehidupan menggereja terutama berkaitan tentang katekese umat. Katekese umat berupaya untuk membuat hubungan antara pengalaman, situasi dan kondisi setiap umat dengan pengalaman Kitab suci (2018:241-242).

\begin{abstract}
Sasaran Katekese umat adalah komunikasi iman yang memungkinkan peseerta semakin menyadari kehadiran-Nya dalam kenyataan atau pengalaman hidup sehari-hari, seperti menurut Paulus: "Bukan aku lagi yang hidup, melainkan Kristus yang hidup dalam aku” (Gal 2:20). Dengan Proses demikian peserta semakin beriman, berharap, mengamalkan cinta kasih dan makin dikukuhkan hidup kristianinya. Jika memang demikian halnya, hilanglah jurang yang memisahkan antara agama dengan hidup sehari-hari: agama dihayati dalam hidup yang profan dan hidup biasa jadi medan perjumpaan dengan Allah. Melalui katekese umat, peserta mengalami dan menyadari bahwa seluruh dunia termasuk segala pengalaman hidup setiap orang ditebus oleh Kristus dan mengantarnya kepada Allah Bapa (bdk.EG 132).
\end{abstract}

Segala pengalaman hidup merupakan pengalaman perjumpaan dengan Allah. Iman itu berwujud dalam kehidupan konkret dimana juga menjadi wadah pengalaman iman umat Gereja awali. Dengan demikian, katekese umat membuka diri bagi pengalaman iman Gereja awali. Disadari bahwa katekese umat adalah suatu proses maka penggunaan Alkitab dalam proses tersebut bukanlah semata-mata soal menemukan teks yang tepat, melainkan soal membiasakan diri terbuka akan pengalaman orang lain, dan terutama pengalaman tokoh-tokoh alkitabiah (Hardawiryana, 1989:30). Aneka perjumpaan dengan Allah dalam macam-macam wujud konkret hidup Gereja awali juga terjadi hari ini: "Dengan demikian, kita membiarkan diri dibarui dalam Kristus dengan hidu yang “menurut Roh” (Rom 8:5)” (EG 162).

Pendampingan dalam katekese umat sungguh menolong terlebih apabila sesuai dengan situasi umat setempat. Suasana akan menjadi hidup dan tidak monoton dalam proses pemahaman dalam berkatekese bersama umat. Katekese membawa pada kesadaran akan beriman yang kontekstual, gagasan akan inkarnasi sebagai contoh akan menjadi konkret dimana hidup umat menjadi hidup, bergerak dan ada dalam konteks yang sesuai untuk memperluas refleksi dalam pengalaman beriman yang saling dibagikan satu sama lain.

Gereja sering mendapatkan stigma negatif bahwa Gereja kurang membumi, para gembala tidak berbau domba, dan berbagai stigma lain yang hendak mengabarkan bahwa Gereja kurang peduli dengan apa yang dialami oleh umatnya. Namun pada kenyataan Gereja terus berusaha untuk mendekatkan diri, menyapa umat maupun menjawab kebutuhan umat dengan berbagai caranya berdasarkan hasil yang didapatkan dalam penilitian terdapat sebanyak 81 responden atau 64,8\% menyatakan bahwa mahasiswa "selalu” merasakan bahwa Gereja tetap menyapa dan sungguh hadir dalam pembinaan iman, 30 responden atau 24\% menyatakan 
“beberapa kali”, 12 responden atau 9,6\% menyatakan “jarang” dan 2 responden atau 1,6\% menyatakan "tidak pernah". Perlu diakui bahwa dalam angka Gereja masih memiliki cukup pekerjaan rumah terutama bagi pelayanan bagi kaum muda terkhusus bagi mahasiswa Katolik yang merantau di Malang. Gereja belum sungguh dirasakan kehadirannya dalam usaha untuk mendekatkan diri kepada umat awam terutama dalam pembinaan iman umat.

Berbagai keterbatasan mulai dari sarana prasarana dalam berpastoral bagi kaum muda, pelayanan pastoral bagi kaum muda maupun kesempatan untuk berkumpul bersama semua serba terbatas dan mendapatkan pembatasan. Gereja dalam misinya untuk mewartakan Kerajaan Allah di tengah dunia cukup mendapatkan tantangan yang tidaklah mudah. Gereja harus tutup dan membatasi orang yang dapat datang, keterbatasan umat yang harus mengikuti kegiatan-kegiatan Gereja maupun Perayaan Ekaristi secara online yang terkendala biaya, jaringan maupun kuota data internet maupun kecanggungan dalam memanfaatkan teknologi tidak dapat dipungkiri.

Rasa ditinggalkan oleh Gereja juga bisa tumbuh dalam perasaan mahasiswa Katolik yang merantau ke Malang. Dalam hasil penelitian berdasarkan pertanyaan uraian “Apa harapanku sebagai mahasiswa Katolik yang merantau di Malang selama pandemi Covid-19 bagi kehidupan Gereja?”, terdapat beberapa ungkapan harapan mahasiswa Katolik yang merantau ke Malang agar pandemi segera berakhir, supaya bisa merayakan Ekaristi di Gereja seperti semula dan bisa berkumpul bersama umat yang lain tanpa ada jarak. "Gereja paroki tempatku tinggal lebih memperhatikan kami dengan cara tidak mempersulit kami anak perantauan dalam hal mengikuti Perayaaan Ekatisti secara langsung di Gereja” maupun terdapat antusiasme yang terungkap dalam kalimat "Semoga Gereja tetap hadir dalam membina iman saya sebagai perantau dan juga sebagai mahasiswa."

Dalam dokumen akhir Sinode para Uskup tahun 2018 tentang Orang Muda, Iman, dan Penegasan Panggilan. Dalam Artikel 16 dengan tema “Kegiatan-kegiatan pastoral orang muda”, dituliskan demikian:

"Dalam perjalanan Sinode, muncul kebutuhan untuk memberi dimensi panggilan dalam pastoral orang muda, dengan mempertimbangkan semua orang muda sebagai sasaran pastoral panggilan. Bersama-sama kami juga menggarisbawahi perlunya mengembangkan proses pastoral yang lengkap, sejak masa anak-anak hingga masa dewasa dan memasuki komunitas Kristiani. Juga perlu diperhatikan bahwa berbagai kelompok paroki, gerakan-gerakan, dan perkumpulan-perkumpulan orang muda melakukan proses yang efektif untuk pendampingan dan formasio orang muda dalam hidup iman mereka.

Hari Orang Muda Sedunia -lahir dari intuisi profetis Santo Yohanes Paulus II, yang menjadi kerangka acuan juga bagi orang muda dari milenium ketiga, bersama-sama dengan pertemuan-pertemuan 
orang muda tingkat nasional dan keuskupan memiliki peran penting dalam hidup banyak orang muda sebab memberikan pengalaman hidup akan iman dan pesekutuan, yang membantu mereka menghadapi tantangan-tantangan besar dalam hidup dan untuk mengambil tempat mereka dalam masyarakat dan dalam komunitas gerejawi secara bertanggung jawab. Pertemuan-pertemuan semacam ini dapat menjadi acuan dalam pendampingan pastoral rutin di tiap-tiap komunitas, di mana penerimaan Injil harus diperdalam dan diterjemahkan ke dalam pilihan-pilihan hidup”.

Gereja sejak dulu selalu memiliki komitmen untuk mengusahakan banyak hal untuk kaum muda terutama dalam membuat kaum muda berkumpul untuk berdoa, bersekutu maupun saling menguatkan satu sama lain. Pertemuan itu begitu penting dalam membangun dialog, maka dari itu Gereja senantiasa mengusahakan suatu bentuk pertemuan yang dapat dilakukan secara bersama. Namun pertemuan dan usaha untuk berkumpul dalam suatu kegiatan ataupun doa secara fisik hadir menjadi terhambat dan mendapatkan pembatasan. Pandemi Covid-19 yang kini sedang dialami bukan hanya di alami oleh Gereja tetapi juga masyarakat dunia. Pembatasan pertemuan cukup membatasi ruang gerak Gereja untuk mendekati kaum muda. Namun apakah pembatasan itu benar-benar membatasi Gereja?

Gereja memiliki peran penting dalam hidup banyak orang muda sebab memberikan pengalaman hidup akan iman dan persekutuan yang mampu membantu kaum muda untuk menghadapi tantangan-tantangan besar dalam hidup beriman maupun hidup di tengah masyarakat yang bertanggung jawab. Orang Muda Katolik merupakan masa depan Gereja, karena kehadiran orang muda akan memberikan harapan Gereja masa depan untuk dapat bertahan. Kehadiran orang muda dalam Gereja harus mendapatkan perhatian yang besar dalam pembinaan, terlebih bagaimana membawa orang muda pada sebuah Gereja yang hidup, hal ini senada dengan Seri Dokumen Gereja No.107 tentang Orang Muda, Iman, dan Penegasan Panggilan Artikel 51:

Dalam berbagai konteks, orang-orang muda Katolik menghendaki kesempatan-kesempatan doa dan saat-saat sakramentali yang dapat menyentuh kehidupan sehari-sehari mereka dengan sebuah liturgi yang segar, autentik dan penuh sukacita. Di berbagai belahan dunia, pengalaman liturgis adalah sumber utama bagi identitas Kristiani dan membuka partisipasi luas dan meyakinkan. Orang-orang muda melihatnya sebagai sebuah momen istimewa pengalaman akan Allah dan akan komunitas Kristiani, serta merupakan titik awal misi. Sebaliknya, di tempat lain, sakramen-sakramen dan Ekaristi hari Minggu mulai ditinggalkan, sebab dipandang lebih sebagai perintah moral daripada sebuah perjumpaan penuh sukacita dengan Tuhan yang bangkit dan dengan komunitas. Secara umum, tampak bahwa walaupun diberikan katekese tentang sakramen-sakramen, pendampingan edukatif untuk menghayati perayaan secara 
mendalam, untuk masuk ke dalam kekayaan misteri, simbol-simbol dan ritus-ritusnya, masih lemah.

Fakta perkembangan kaum muda meliputi suatu dinamika kompleks berupa fisik, emosional, mental, moral, sosial dan religius. Penggunaan bahasa harus sesuai zamannya, tanpa harus menghilangkan makna atau maksud dari apa yang hendak disampaikan dengan bertitik tolak dalam Seri Dokumen Gereja No.107 tentang Orang Muda, Iman, dan Penegasan Panggilan Artikel 54:

Orang-orang muda Katolik bukan sekedar objek karya pastoral, melainkan anggota hidup dari tubuh Gereja yang satu, mereka telah dibaptis dan di dalam mereka Roh Tuhan hidup dan berkarya. Mereka ikut serta memperkaya keberadaan Gereja dan bukan sekadar apa yang dilakukan Gereja. Mereka adalah masa sekarang dan bukan hanya masa depan Gereja. Orang muda adalah pelaku utama dari banyak aktivitas gerejawi, di mana mereka menawarkan pelayanan mereka secara murah hati, khususnya dengan animasi katekese dan liturgi, perhatian terhadap mereka yang terkecil, relawan untuk orang-orang miskin. Gerakan-gerakan, perkumpulan-perkumpulan, serta kongregasi-kongregasi religius juga menawarkan kepada orang-orang muda peluang-peluang untuk berkomitmen dan bertanggung jawab. Kadang-kadang, kesiapsediaan orang-orang muda berhadapan dengan autoritarianisme dan ketidakpercayaan kaum dewasa dan para gembala, yang tidak cukup mengakui kreativitas dan usaha keras mereka untuk berbagi tanggung jawab.

Orang Muda Katolik dalam perkembangan zaman terus berdinamika dalam hidup beriman terutama dalam budaya populer, maka hendaknya budaya populer dijadikan sebagai sarana untuk berdialog dan menyampaikan nilai-nilai hidup kepada kaum muda. Budaya populer sendiri merupakan salah satu sumber spiritual yang mungkin akan dipilih oleh remaja (bdk. Kurniawan, 2016:7).

Penekanan pada pewarta sangatlah penting. Pewarta (subjek tutur) hendaknya melakukan pembaharuan terkait formulasi ujaran (bagaimana mengemasi isi pewartaan) sehingga bahasa pewartaan memiliki makna dan mudah dipahami oleh pendengar, dalam hal ini ialah kaum muda (bdk. Pandor: 2018, 193). Menurut Mgr. Riana Prabdi, seni dan olahraga merupakan kesempatan untuk menjumpai orang muda. Sekaligus, melalui kedua bidang itu para pendamping dapat membantu, menemani, dan membawa mereka menuju kekudusan (Dokpenkwi.org).

Melalui Indonesia Youth Day 2016 di Manado pada tanggal 1-6 Oktober 2016, 2.458 Orang Muda Katolik se-Indonesia yang didampingi 149 imam, 4 biarawan dan 24 biarawati, para pendamping awam serta 23 Uskup, menegaskan "kami menyadari bahwa kami dipanggil secara proaktif dan kritis untuk menjadi garam dan terang dunia. Melalui kerahiman Allah, kami diajak untuk memulihkan 
kehidupan yang didasarkan pada: penghormatan terhadap martabat manusia, pelestarian lingkungan hidup, peningkatan kesejahteraan, keberpihakan terhadap kaum kecil, lemah, miskin, tersingkir dan difabel. Kami terpanggil untuk menjadi penggerak yang inspiratif dan berintegritas dalam mewujudkan perubahan sosial-politik di setiap tingkatan karya untuk tata dunia yang lebih adil dan manusiawi” (Dokpenkwi.org).

Peran Orang Muda Katolik dalam Gereja bagaikan koin bersisi dua yang bisa membantu memajukan Gereja maupun menghancurkan Gereja, semua itu tergantung bagaimana setiap pihak terutama bagi Gereja maupun Orang Muda. Gereja berkembang maupun terpuruk tergantung pada kita sendiri sebagai anggota Gereja.

\section{KESIMPULAN}

Gereja disebut Katolik karena terbuka dan diperuntukkan untuk siapa saja. Gereja bukan milik sebagian orang tetapi semua kita yang menjadi anggotanya. Gereja dalam masa pandemi pun hendaknya menjadi Gereja yang mengayomi umatnya, karena misi Gereja tidak terlepas dari pada rencana keselamatan Allah dalam sejarah kehidupan manusia yang dimulai sejak awal mula, yakni sejak Allah menciptakan dunia dan segala isinya. Situasi pandemi Covid-19 yang dialami dunia dan Gereja membuat banyak pembatasan dalam rangka kemanusiaan, bersolider dan peduli pada keselamatan orang lain.

Pandemi Covid-19 memaksa Gereja untuk menjaga batasan-batasan agar memutus dan meminimalisir penularan. Mahasiswa Katolik yang merantau ke Malang menjadi salah satu dari sekian banyak orang yang terdampak akibat adanya virus corona dan kebijakan-kebijakan yang ada. Mahasiswa perantau yang memahami bahaya virus dan pencegahannya harus dengan lapang dada menerima kesulitan-kesulitan dalam beribadah ataupun aktif dalam kegiatan kegerejaan. Gereja Lokal memberlakukan pembatasan bagi mereka yang bukan anggota dari paroki ataupun wilayah Gereja lokal untuk bergabung. Walaupun demikian Gereja tetap setia dengan cara-cara mengusahakan pelayanan terhadap para perantau tanpa mengurangi prioritas gereja lokal pada anggota wilayah Gereja tersebut. Gereja tidak dirasakan oleh mahasiswa rantau sebagai Gereja yang tertutup dan menghindar dengan keadaan. Gereja berusaha dengan keterbatasan dan tetap menjalankan protokol kesehatan, supaya pelayanan kepada umat Allah tidak menyebabkan suatu penyebaran virus yang justru akan menyengsarakan. 


\section{DAFTAR PUSTAKA}

Aman, Peter C., 2016, Moral Dasar Prinsip-prinsip Pokok Hidup Kristiani. Jakarta: Obor

Anangguru Yewangoe, Andreas., 2017, “Konsili Vatikan II, 50 Tahun Kemudian”, dalam Jurnal Ledalero Vol. 12 No. 1, Maumere

Amiman, R. V., 2018, "Penatalayanan Gereja Di Bidang Misi Sebagai Kontribusi Bagi Pelaksanaan Misi Gereja”, dalam Missio Ecclesiae Vol. 7 No. 2, Batu.

Bagiyowinadi, F.X. Didik., 2014, Siap Menjadi Pengurus Lingkungan, Jakarta: Obor.

Charles M, Shelton., 1987, Spiritualitas Kaum Muda, Yogyakarta: Kanisius.

Denny Firmanto, Antonius., 2011, “Umat Awam Dalam Dinamika Hidup Gereja, dalam Studia Philosophica Et Theologica, Vol. 11 No. 2, Malang.

Denny Firmanto, Antonius., 2017, "Kehadiran Gereja Di Ruang Publik Perspektif Eklesiologis Di Dalam Memandang Keadaan Akhir-Akhir Ini”, dalam Seri Filsafat \& Teologi, Vol. 27 No. Seri 26, Malang.

Denny Firmanto, Antonius., 2018, “Katekese Umat”, dalam Seri Filsafat Teologi Widya Sasana, Vol. 28 No. 27, Malang.

Dien, N., 2020, “Gereja Persekutuan Umat Allah. Media”, dalam Jurnal Filsafat dan Teologi Vol. 1 No. 1, Pineleng

Dwiraharjo, S., 2020, “Konstruksi Teologis Gereja Digital: Sebuah Refleksi Biblis Ibadah Online Di Masa Pandemi Covid-19”, dalam EPIGRAPHE: Jurnal Teologi dan Pelayanan Kristiani, Vol. 4 No. 1, Surakarta.

Handayani, P. G., \& Yuca, V., 2018, "Fenomena Culture Shock Pada Mahasiswa Perantauan Tingkat 1 Universitas Negeri Padang”, dalam Jurnal Konseling Dan Pendidikan Vol. 6 No. 3, Padang.

Januari, V., 2016, “Kaum Muda sebagai Gereja” dalam Jurnal Youth Ministry Vol.4 No. 1, Jakarta.

Kleden, Paul Budi, 2006, Membongkar Derita, Maumere: Penerbit Ledalero.

Kristiono, R., 2019, “Bonus Demografi Sebagai Peluang Pelayanan Misi Gereja di Kalangan Muda-Mudi”, dalam Jurnal Teologi Berita Hidup Vol. 1 No. 2, Jakarta.

Pandor, Pius., 2018, “Kontribusi Teori Ujaran dan Tindakan Bahasa Dalam Filsafat Analitik Jhon Langshaw Austin Terhadap Bahasa Pewartaan”, dalamSeri Filsafat Teologi Widya Sasana Vol. 28 No. 27, Malang

Prihanto, A., 2018, "Peran Proses Mentoring Pemimpin Kaum Muda Bagi Perkembangan Pelayanan Pemuda Di Gereja”, dalam Jurnal Jaffray Vol. 16 No. 2, Jakarta. 
Purwaningtyas, M. P. F., 2020, "Ketidakpercayaan dan Eskapisme Kaum Muda Menghadapi Paparan Informasi Covid-19”, dalam ETTISAL: Journal of Communication Vol. 5 No. 2, Ponorogo.

Rahail, M. M., Wahyudi, I., \& Widiantoro, F. W., 2020, “Hubungan Antara Kohesivitas Kelompok dengan Dukungan Sosial bagi Mahasiswa Perantau yang Aktif di Organisasi Orang Muda Katolik, Gereja X Yogyakarta”, dalam Jurnal Psikologi Vol. 16 No.1, Yogyakarta.

Raho, Bernard., 2013, Agama dalam Perspektif Sosiologi. Jakarta: Obor.

Saragih, A., \& Hasugian, J. W., 2020, "Model Asuhan Keluarga Kristen Di Masa Pandemi Covid-19” dalam Jurnal Teruna Bhakti Vol. 3 No. 1, Yogyakarta.

Sermada Kelen, Donatus., 2017, “Agama Dalam Ruang Publik Di Indonesia dan Posisi Gereja Katolik-Satu Telaah Filsafat Sosial”, dalam Seri Filsafat \& Teologi, Vol. 27 No. Seri 26, Malang.

Sholichah, I. F., 2018, “Identitas Sosial Mahasiswa Perantau Etnis Madura”, dalam PSIKOSAINS (Jurnal Penelitian dan Pemikiran Psikologi) Vol .11 No.1, Gresik.

Situmorang, Markus., 2018, “Kaum Awam dan Pembaharuan Gereja Dalam Terang Konsili Vatikan II”, dalam Seri Filsafat Teologi Widya Sasana Vol. 28 No. 27, Malang.

Sobrino, Jon., 1994, Christology at The Crossroads, New York: Orbis.

Tri Wardoyo, Gregorius., 2019, “Immortalitas/Umur Panjang: Antara Rencana Manusia dan Allah”, dalam Seri Filsafat \& Teologi, Vol. 29 No. 28, Malang.

Widjaja, F. I., Marisi, C. G., Togatorop, T. M. T., \& Hartono, H., 2020, “Menstimulasi Praktik Gereja Rumah Di Tengah Pandemi Covid-19”, dalam Kurios (Jurnal Teologi dan Pendidikan Agama Kristen) Vol. 6 No. 1, Jakarta.

Yuono, Y. R., 2020, “Pertumbuhan Gereja Di Masa Pandemi”, dalam SAGACITY: Journal of Theology and Christian Education Vol. 1 No. 1, Salatiga.

Zaharah, Galia Ildusovna Kirilova, Anissa Windarti, 2020, "Impact of Corona Virus Outbreak Towards Teaching and Learning Activities in Indonesia”, dalam Salam: Jurnal Sosial dan Budaya Syar-i. Volume 7 No. 3, Jakarta.

\section{Dokumen Gereja}

Dokumen KWI., 1990. “Lumen Gentium” dalam Dokumen Konsili Vatikan II, terj. R. Hardawiryarna, S.J. Jakarta

Dokumen KWI., 2019, Orang Muda, Iman, Dan Penegasan Panggilan: Seri Dokumen Gerejawi No. 107, Dokumen Akhir dari Sidang Umum Biasa XV Sinode Para Uskup 27 Oktober 2018. Diterjemahkan oleh: Sr. Caroline 
Nugroho MC Editor: Andreas Suparman SCJ \& Bernadeta Harini Tri Prasasti. Jakarta.

Dokumen KWI., 2020, Surat Apostolik Paus Fransiskus "Patris Corde"

Diterjemahkan oleh Bernadeta Harini Tri Prasasti, Jakarta.

Dokumen KWI., 1991, Dekrit Ad Gentes. Jakarta.

Dokumen KWI., 1990, Redemptoris Missio (Tugas Perutusan Sang Penebus): Seri

Dokumen Gerejani No. 14 Ensiklik Bapa Suci Yohanes Paulus II tentang Amanat Misioner Gereja. Jakarta.

\section{Internet}

https://www.dokpenkwi.org/2020/05/03/mgr-pius-riana-prapdi-allah-memanggilm u-orang-muda/ diakses pada 14 April 2021 pada pkl. 18.38Wib.

https://www.dokpenkwi.org/2016/10/13/iyd-2016-manado-ikrar-orang-muda-Kato

lik -pada-indonesian-youth-day-2016-di-manado/ diakses pada 14 April 2021 pada pkl. 18.39Wib.

https://docs.google.com/forms/d/1in-oF21rczK9GDEhcEsir9HGc5HD1OBIWrS4

2pftK3c/edit\#responses diakses pada 14 April 2021 pkl. 16:36 Wib. 